\title{
The Student Experience In Speed Teaming: A New Approach To Team Formation
}

Randall S. Hansen, (rhansen@stetson.edu), Stetson University Katharine Hansen, Union Institute and University

\begin{abstract}
Building on previous research by the first author, this paper presents data from students who experienced an innovative method of team development based on a concept coined "Speed Teaming."
\end{abstract}

\section{PURPOSE}

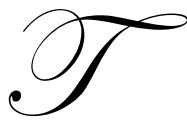

he purpose of this study was to review existing methods for placing students into work teams and experiment with an innovative method that uses student input to build the teams while giving the professor ultimate control in the final groupings, forming a hybrid new category of team selection.

Thus, after studying a social phenomenon called "Speed Dating," the researchers modified the rules and applied a similar approach to team formation dubbed "Speed Teaming."

Recognizing that the trends affecting organizational structure have led to more participative management, flatter hierarchies, and work organized into self-directed teams, business faculty have been placing students in work groups for quite some time (Bolton, 1999; Siciliano, 1999). As the use of work teams in organizations increased, the use of team projects in education also grew (Bolton, 1999). Because employers seek team players among newly graduated business students, teams, and more importantly, the ability to work in teams - and to lead teams - has become an important skill for workers to master (McCorkle et al, 1999; Thacker \& Yost, 2002; Tarricone \& Luca, 2002). Teamwork skills (learning experiences in group dynamics) even comprise a learning standard that AACSB expects of its member institutions to impart on their students as part of accreditation (AACSB, 2005).

Many benefits accrue for students when they work in teams. Researchers have shown that the learning-bydoing approach of group projects results in active learning and far greater comprehension and retention (Cross, 1981; Kolb, 1984; McLagan, 1985; Pike, 1989), higher levels of student achievement (Wulff, Nyquist, \& Abbott, 1987), accomplishment of sophisticated learning objectives (Bailey et al, 2005), the development of critical reasoning skills (Gabbert, Johnson, \& Johnson, 1986), and improved communications skills (Meyer, 1994; Williams, Beard, \& Rymer, 1991) than is found with traditional lecture-style teaching methods (Ashraf, 2004; Williams, Beard, \& Rymer, 1991).

Overall, most research shows that students at both the undergraduate and graduate level respond favorably to group projects and suggests that team assignments are useful in team skills acquisition (Deeter-Schmeltz \& Ramsey, 1998; Ford \& Morice, 2003; McCorkle et al, 1999; McKinney \& Graham-Buxton, 1993; Hernandez, 2002). One of the few exceptions is Bacon (2005), who found that the use of group projects actually inhibited learning.

Problems with student teams - including lack of leadership, scheduling conflicts, lack of team development, free-riding/social loafing, and students who prefer to work alone (Ashraf, 2004; Beard, Rymer, \& Williams, 1989; Burleson, Levine, \& Samter, 1984; Cox \& Bobrowski, 2000; Joyce, 1999; McCorkle et al, 1999; Mello, 1993; Pfaff \& Huddleston, 2003; Rotfeld, 1998; Shea, 1995; Williams, Beard, \& Rymer, 1991) - often start at formation. As Hamlyn-Harris, Hurst, von Baggo, and Bayley note, "Team composition ... can be manipulated in an academic environment” (2006, p. 303). Two main team-selection methods are commonly used: professor-selected and studentselected, as described in Exhibit 1. (Some authors call random assignment a third category, but because the instructor 
decides on random assignment, it is placed in the professor-selected category for this paper.) Although traditionally some researchers have recommended that faculty assign students to teams (Feichtner \& Davis, 1985; Michaelsen, 1994; Muller, 1989; Proll, 1972), Connerley and Mael (2001) (similarly Smith, Adams, Mendelson, \& Sibeck, n.d.) report that this procedure is unpopular with students, while other researchers recommend student-selection because it may lead to better cohesion and less conflict (Koppenhaver \& Shrader, 2003; Latting \& Raffoul, 1991; Strong \& Anderson, 1990) and more ownership (Mello, 1993), and thus fewer problems (Pfaff \& Huddleston, 2003) and a better a better team experience (Bacon, Stewart, \& Silver, 1999; Ettington \& Camp, 2002). Both team formation methods, though, present problems.

\section{Exhibit 1: Student Team Selection Methods}

Professor-Selected:

- Instructor randomly assigns students into groups without regard for student preferences, needs, or skills.

- Instructor assigns students into groups based on knowledge of student competencies, skills, and personal characteristics (from responses to questionnaire), but with no regard to student preferences.

- Instructor presents a list of projects and asks students to sign themselves into any unfilled teams.

- Instructor asks students to rank a list of projects/topics in order of preferences, and then places students into groups based on rankings.

- Instructor assigns students into teams by proximity; thus, students sitting next to each other are placed into the same team.

Student-Selected:

- $\quad$ Students choose their friends or close associates, leaving behind some students who need to be placed into groups.

- $\quad$ Students choose the people nearest to them, again leaving some students to be assigned into groups.

- $\quad$ Students bid on tasks, projects, or actual members in a process similar to an auction or free market.

Sources: Bacon, Stewart, \& Solver, 1999; Beheshtian-Ardekani \& Mahmood, 1986; Beaman \& Stolz, 1992; Chervany \& Heinen, 1975; Hill, Naumann, \& Chervany, 1983; Koppenhaver \& Shrader, 2003; Muller, 1989; Oliphant \& Hansen, 1996; Proll, 1972; Verderber \& Serey, 1996.

Several problems may arise when the professor selects the groups. The instructor faces the extra work necessary to organize and manage the process (even if random methods are used), can face difficulty in implementing the process, and can encounter resentment and blame if conflicts arising within the groups result in a poor outcome (Bacon, Steward, \& Silver, 1999; Beaman \& Stolz, 1992; Holter, 1994; Verderber \& Serey, 1996).

Student-selected groups also present numerous issues, including groups with no leaders (Beaman \& Stolz, 1992); groups with limited perspectives (Jalajas \& Sutton, 1984-85; Muller, 1989); and groups with students no one else wanted (Beaman \& Stolz, 1992). Part of the problem is that students who are instructed to choose their own teams are rarely provided with any criteria or basis for which to select team members, thus often choosing team members based on their social network of friends (Levine \& Moreland, 1990). The research of Hamlyn-Harris, Hurst, von Baggo, and Bayley (2006), in fact, showed no correlation between working with friends on teams and team satisfaction.

Limited evidence supports the notion that professor-selected groups are seldom used (Bacon, Stewart, \& Silver, 1999; Decker, 1995), possibly because student-selected groups perform better than professor-selected teams (Connerley \& Mael, 2001; Faria \& Wellington, 1989). However, Muller (1989) states that student preferences are not necessarily the most important criterion for successful group work, while Koppenhaver and Shrader (2003) suggest that instructor-assigned teams lead to more stability in membership, and that stability enhances each team's ability to perform effectively. Faculty may also choose to select team members to establish diversity within the teams (McCain, 1996; Tonn \& Milledge, 2002). Contrary to earlier research, Hernandez (2002) states that student teams should be formed by the instructor, and that students are more likely to engage in a positive learning experience when the professor selects the groups. 
The literature marginally touches on such aspects of team formation as the value of preliminary training and “icebreaker" activities (Barker \& Franzak, 1997), use of the Myers-Briggs Type Indicator (Amato \& Amato, 2005; Clinebell \& Stecher, 2003) and other personality assessments (van Vianen \& De Dreu, 2001; McClough \& Rogelberg, 2003), adequacy of time students have known prospective teammates before making a selection, and criteria students are most likely to use in self-selecting teammates. This study attempts to fill some of these knowledge gaps.

\section{PROCEDURE}

The Speed Teaming method is adapted from the theory and premise of speed dating. Speed dating was invented in the late 1990s by a Los Angeles rabbi determined to help marriage-focused Jewish singles to meet, and has been called the most significant shift in American dating culture since the mid-1960s (Barker, 2003). The premise of speed dating is that an equal number of men and women arrive in a venue, are given nametags (first name only), a scoresheet (with yes/no columns), and a set of rules about the types of questions that are allowed. The scoresheet allows participants to choose whom they would like to meet for a traditional date. In speed dating, couples spend anywhere from 3 to 10 minutes in a conversation-driven mini-date before a whistle blows and each must move on to a new person. Before they move, however, they mark their scoresheet. If both parties express interest in the other, the organizers facilitate an exchange of contact information.

Critics of speed dating argue that the process is far too shallow because most decisions are made in the first few seconds on first impressions (Spears, 2005), while supporters stress that first impressions are critical - in dating, in job interviewing, and on the job. First impressions are often made before a word is even spoken and can lead to a halo effect that impacts the entire impression of the individual (Simons, 1995). Supporters also argue that compatibility or rapport can also be very quickly established - or found to be lacking. And for teams to function effectively, Jackson et al (1991) state that the interpersonal compatibility of members is likely to be an important factor.

Interestingly, others have taken the concept of speed dating and applied it to business. For example, the U.S. Small Business Administration (SBA) offers a program in which small-business owners spend 15 minutes with contracting executives before a bell rings, and they switch chairs to meet the next executive. The SBA says that about $\$ 30$ million of contracts have been struck through the program since its launch last year (Cutler, 2005). And Apple Computer Corporation used a speed-dating approach to connect Apple specialists with vendors at two conferences (Business Wire, 2005). Several groups are also using the speed-dating method as an approach for networking for local young professionals groups, chambers of commerce, and other business groups (Arney, 2005; Crawley, 2005; Norman, 2005).

In Speed Teaming, we take the benefits and lessons of speed dating - the power of first impressions, the need to ask the right questions, and build rapport - and empower students to make choices about potential team members. We also incorporate some elements of job interviewing by encouraging students to engage each other on typical interview-related subjects such as work ethics, communications skills, and leadership. Furthermore, because of the importance of understanding personality-type differences in relation to team dynamics (Amato \& Amato, 2005; Clinebell \& Stecher, 2003), students are encouraged to ask about Myers-Briggs Type Indicator (MBTI) types and other assessment results.

Only five steps are required for planning and implementing Speed Teaming, as shown in Exhibit 2. 


\section{Exhibit 2: Steps to Speed Teaming}

Step 1. Before class, develop a team ballot with each student's name and a "yes" and "no" box next to it.

Step 2. Before class, divide students into equal groups, assigning each student a row number. For example, if you have four groups of 8 students, you would have four rows with 8 students in each row.

Step 3. At the start of class, students are given a nametag and ballot, along with a copy of the rules (see Exhibit 4 for details), and assigned to a specific group. Students are also presented with a handout of questions they might want to ask during the process (see Exhibit 5 for details). To remind students of the rules, the professor could also write them or project them onto the board.

Step 4. The interviews begin! Every two minutes (or longer if you have the time) the whistle is blown and students mark their ballots - and half of the groups rotate (by moving over one chair) to the next interview, while the other half stay seated. This process continues until all students have a chance to interview each member of the class. (Be prepared; this event gets very loud.)

Step 5. At the end of the exercise, the ballots are collected. At a later time, away from the class, the instructor identifies the most popular choices and use these students as anchors for the total number of groups, and then assigns students to each group based on the results of the balloting.

The first step in Speed Teaming is developing the team ballot. The ballot is a three-column roster of student names and boxes (or lines) for checking yes or no. Directions or rules could also be included on the ballot.

The second step involves dividing students into equal numbeed groups. For example, the classes used for this research contained 24 and 25 students, so students in one class were organized into four groups of 8 , and in the other class, 3 groups of 8 and one of 9 .

In the third step, upon arriving to the class, students are given a nametag and ballot, along with a copy of the rules (see Exhibit 3 for details), and assigned to a specific group. Students are also provided with a series of questions they might want to ask during the process (see Exhibit 4 for details). The list of questions can certainly be shortened or adapted to fit the need of the class; the list in Exhibit 4 was developed from numerous sources, including focus groups conducted with teams from previous courses.

\section{Exhibit 3: Speed Teaming Rules}

Here are the rules of Speed Teaming:

1. This is a timed event. You have 2 minutes per interview.

2. Take a moment and make a plan for what you need to ask in the interviews. (see the list of potential questions to ask.)

3. You may want to consider your strengths and weaknesses.

4. You can choose up to 10 people for your team, and you can reject (say no to) only up to 5 people for your team.

5. You cannot ask if the other person wants you on his/her team - and you cannot reveal your preference.

6. Remember the importance of first impressions - but also remember to look beyond them and use all your time in making a decision.

7. At the whistle, make your decision, mark your ballot, and move according to the instructions given you.

8. Ballots are confidential and will be destroyed after teams have been formed. 


\begin{tabular}{|c|c|}
\hline \multicolumn{2}{|c|}{ Exhibit 4: Questions You Might Ask During Speed Teaming } \\
\hline $\begin{array}{l}\text { (Pick the best ones to ask in the short time you have to ask } \\
\text { them!) } \\
\text { - What are your best skills? } \\
\text { - } \text { Are you more energetic or laid back? } \\
\text { - Do you like a fast or slow pace? } \\
\text { - Are you a planner? } \\
\text { - Are you a leader? } \\
\text { - } \text { Do you like working with others? } \\
\text { - How do you get along with other people? } \\
\text { - } \text { Would you consider yourself friendly? } \\
\text { - Are you rational or instinctive? } \\
\text { - Are you more an introvert or extravert? } \\
\text { - Are you open to new ideas, opinions, perspectives? } \\
\text { - Do you have a sense of humor? } \\
\text { - How organized are you? } \\
\text { - } \text { Are you dependable? } \\
\text { - } \text { Can you meu responsibility for your actions? }\end{array}$ & $\begin{array}{l}\text { - } \quad \text { Are you open to the idea of working in a team? } \\
\text { - } \quad \text { Have you worked in teams before? } \\
\text { - } \quad \text { Can you work on weekends? } \\
\text { - } \quad \text { When do you get your best work done? } \\
\text { - } \quad \text { How wou goal-oriented? } \\
\text { - } \quad \text { What's one word that sums up who you are? } \\
\text { - } \quad \text { Do you play sports? } \\
\text { - } \quad \text { Do you live on campus? } \\
\text { - } \quad \text { What's your schedule look like? } \\
\text { - } \quad \text { Are you a talker or a listener? } \\
\text { - } \quad \text { Are you consider yourself flexible? } \\
\text { - } \quad \text { Can you see yourself getting along with me? } \\
\text { - } \quad \text { Are you a worker or a slacker? } \\
\text { - } \quad \text { Do you willing to do your share of the work? } \\
\text { - } \quad \text { Are you tolerant of others who are not like you? } \\
\text { - } \quad \text { What's your Myers-Briggs type? } \\
\text { What are your TrueColors main colors? }\end{array}$ \\
\hline
\end{tabular}

The fourth step begins once all the students understand the process and agree to the rules. The instructor blows the whistle for the first interview to begin. Two minutes later, the whistle is blown again, and students are told to mark their ballots - and half of the groups rotate to the next interview (by moving one seat over), while half of groups stay seated. This process continues until all students have a chance to interview each member of the class. See Exhibit 5 for a diagram of the speed-teaming process.

Exhibit 5: A Diagram of the Speed Teaming Process This example is for when four groups are used for speed teaming

\section{Round 1:}

Team 1 and Team 2 (with members of Team 2 rotating one seat down at each two-minute interval) Team 3 and Team 4 (with members of Team 4 rotating one seat down at each two-minute interval)

\section{Round 2:}

Team 1 and Team 4 (with members of Team 4 rotating one seat down at each two-minute interval) Team 3 and Team 2 (with members of Team 2 rotating one seat down at each two-minute interval)

\section{Round 3}

Team 1 and Team 3 (with members of Team 3 rotating one seat down at each two-minute interval) Team 2 and Team 4 (with members of Team 4 rotating one seat down at each two-minute interval)

\section{Round 4:}

Intragroup Interviews, with members of each group pairing up for interviews.

The fifth step involves collecting the ballots at the end of the interviewing process - and placing students into teams. After the ballots have been gathered, in a location outside of class, the instructor begins the process of placing students into teams based on the ballots. The process for completing this step can vary, but the framework used in this project - in which the desired result was 5 equal teams of 5 students - was to find the 5 most frequently selected students and make each a cornerstone for the selection of the remainder of the class into the teams. The only rule we established was that a person could receive no more than 1 "no" and still be included in a group. That is, if more than 1 person from the current members of the group voiced a negative vote on someone, that person was then placed into a different group. 


\section{RESEARCH METHODOLOGY}

We have tested the Speed Teaming method in several classes, but in two particular classes of first-year business students, we asked students to complete an assessment of the Speed Teaming process during the class period immediately following the event.

Students were asked a series of questions about teams and team selection in an assessment we titled, FirstYear Business Experience Team Development Assessment, which was designed to provide a snapshot of how students felt about the value of the Speed Teaming process, about the value of teams and teamwork skills in both college and the workforce, and to rank various elements of successful teams.

Rather than using class time, we distributed copies of the assessment in class and asked students to complete them outside of class and return them at the next class meeting. A total of 48 students completed the assessment.

\section{RESULTS AND DISCUSSION}

These first-year students had been placed in temporary in-class groups several times earlier in the semester to enable them to get to know each other and provide opportunities for students to employ teamwork skills. A number of ice-breaker type exercises were conducted almost daily for the first few weeks of the semester, in which students were placed in groups of people with similar likes, behaviors, or assessment results. Sometimes students were placed in groups based on serious traits (MBTI, TrueColors, archetypes) while other groupings were more whimsical (favorite color, food, high school subject). Besides an initial greeting and introductions, the students were always given a task for the new group to complete, thus training them to work in groups without their awareness that such training was taking place. Tasks included solving a case, debating an issue, discussing a topic, or drawing the group's response. Despite these pre-team-formation activities, many students still did not know each other's names, let alone preferences, strengths, or weaknesses. The speed interviewing gave students one last chance to find the best matches for their teams, and based on initial feedback and noise level in the classroom, students took full advantage of the process.

Surveys focused on student criteria for choosing teammates during Speed Teaming, importance of pre-teamformation activities, sufficiency of knowledge about prospective teammates to make a choice, and preferred teamformation methods.

More than two-thirds (68.75\%) rated the speed teaming exercise as extremely important or important in their choice of potential teammates. None of the students ranked the exercise of no use.

In the research of Hamlyn-Harris, Hurst, von Baggo, and Bayley (2006), pre-team-formation training/activities were shown to affect team satisfaction marginally in one group and not at all in another. In the current study, a high percentage of the students $(70.83 \%)$ found the various small-group activities done in previous classes before the Speed Teaming exercise extremely important or important in their choice of potential teammates. Two students (4.16 percent) found the small-group activities of no use.

Interestingly, less than half of the respondents (43.75\%) felt that they knew enough about their classmates at this point in the semester to make a selection of whom they thought would be the best teammates.

Findings that were peripheral to the Speed-Teaming aspect of the study involved student perceptions of the importance of teamwork skills for college and career success, as well as perceived success factors for teams.

The research of McCorkle et al (1999) found that a vast majority (84.2\%) of student participants recognized the value to their lives and careers of developing teamwork skills. Ford and Morice (2003) found that team projects' reflection of real industry was one of the six most valuable aspects of group assignments. In our study, while students saw the importance of developing teamwork skills for success in both college and career, a much higher percentage perceive teamwork-skills development as more valuable in their careers than in college. While students agreed that 
teamwork skills were extremely important or important to success in college (89.58\%) and career (95.83\%), the difference came in the perception of importance, where only half (52.08\%) felt teamwork skills were extremely important to success in college while more than three-quarters $(77.08 \%)$ felt teamwork skills were extremely important to success in their careers.

In terms of the most important elements of successful teams, students rated the four most important elements (in order of importance): open communication, trust, leadership, and respect.

As for preference in the method of team selection, there was no mistaking how these students feel. Almost two-thirds (62.5\%) prefer self-selection into teams. Far more students had no preference (29.17\%) than for professorchosen $(6.25 \%)$ teams.

\section{LIMITATIONS}

This meet, greet, move-on rapid style of meeting people seemed especially effective to adopt for classes in which students do not know each other - such as for first-year students or newly admitted MBA students - and may not work as well for students who already know each other from previous shared classes and group assignments and may find the exercise repetitive. Speed Teaming obviously would also not work well in extremely large lecture classes.

The process has been tested on a sample of only 7 classes, but it has worked well, and if the results of the post-teaming survey are indicative of the future, the speed-teaming approach could be an answer to the on-going problem of team selection. Of course, more faculty need to adopt and test this process before we can begin to call it a success.

While some anecdotal evidence points to stronger bonds produced through the speed-teaming method than through other selection methods, this method of selection does not address other important issues related to teambuilding and team development (Bolton, 1999; Deeter-Schmeltz, Kennedy, \& Ramsey, 2002; McKendall, 2000; Pfaff \& Huddleston, 2003). This study, for example, neither explores operational team success/performance or satisfaction of team members once teams are formed, nor the extent to which learning may be enhanced through this formation method.

\section{REFERENCES}

1. AACSB (2005). Eligibility procedures and accreditation standards for business accreditation. Tampa, FL: AACSB International.

2. Amato, C. H., \& Amato, L. H. (2005, April). Enhancing student team effectiveness: Application of MyersBriggs personality assessment in business courses. Journal of Marketing Education, 27(1), 41-51.

3. Arney, S. (2005). Business pros make connections; networking event akin to speed dating debuts. Pantagraph, April 13. C1.

4. Ashraf, M. (2004). A critical look at the use of group projects as a pedagogical tool. Journal of Education for Business, 79(4), 213-217.

5. Bacon, D. R. (2005). The effect of group projects on content-related learning. Journal of Management Education, 29(2), 248-267.

6. Bacon, D. R., Stewart, K. A., \& Silver, W. S. (1999). Lessons from the best and worst student team experiences: How a teacher can make a difference. Journal of Management Education, 23(5), 467-488.

7. Bailey, J., Sass M., Swiercz P. M., Seal C., \& Kayes D. C. (2005). Teaching with and through teams: Student-written, instructor-facilitated case writing and the signatory code. Journal of Management Education, 29(1), 39-59.

8. $\quad$ Barker, O. (2003). No time for dating? You're not alone. USA Today, November 12.

9. Beaman, R., \& Stolz, P. G. (1992). A method to the madness: The selection of student public relations groups. Public Relations Review, 18(1), 91-96. 
10. Beard, J. D., Rymer, J., \& Williams, D. L. (1989). An assessment system for collaborative-writing groups: Theory and empirical evaluation. Journal of Business and Technical Communication, 3 (Sept.), 29-51.

11. Beheshtian-Ardekani M., \& Mahmood, M. A. (1986). Development and validation of a tool for assigning students to groups for class projects. Decision Sciences, 17(1), 92-113.

12. Bolton, M. K. (1999). The role of coaching in student teams: A 'Just-in-Time’ approach to learning. Journal of Management Education, 23(3), 233-250.

13. Burleson B. R., Levine, B. J. \& Samter, W. (1984). Decision-making procedure and decision quality. Human Communication Research, 10 (Summer), 557-574.

14. Business Wire (2005). Apple specialists invite vendors to ‘speed dating' event at special Macworld Boston meeting July 11th; pre-show meeting provides vendors unique opportunity to reach dealers. June 14, 1.

15. Clinebell, S., \& Stecher, M. (2003). Teaching teams to be teams: An exercise using the Myers-Briggs Type Indicator and the Five-Factor Personality Traits. Journal of Management Education, 27(3), 362-384.

16. Connerley, M. L., \& Mael, F. A. (2001). The importance of invasiveness of student team selection criteria. Journal of Management Education, 25(5), 471-494.

17. Cox, P. L., \& Bobrowski, P.E. (2000). The team charter assignment: Improving the effectiveness of classroom teams. Journal of Behavioral and Applied Management, 1(1), 92-103.

18. Crawley, N. (2005). Speed dating, networking have a lot in common; Amanda Chocko combines the two concepts in her business: Ready Set Network! The Grand Rapids Press, May 8. H1.

19. Cross, K. P. (1981). Adults as learners: Increasing participation and facilitating learning. San Francisco: Jossey-Bass.

20. Cutler, K. (2005), Small firms try 'speed dating' to ink big deals. Wall Street Journal, June 21. B1.

21. Decker, R. L. (1995). Management team formation for large scale simulations. In J. D. Overby \& A. L. Patz (Eds.), Developments in Business Simulation \& Experimental Exercises (pp. 128-129). Statesboro, GA: Association for Business Simulation and Experiential Learning.

22. Deeter-Schmeltz, D. R., Kennedy, K. N., \& Ramsey, R. (2002). Enriching our understanding of student team effectiveness. Journal of Marketing Education, 24(2), 114-124.

23. Deeter-Schmeltz, D. R., \& Ramsey, R. (1998). Student team performance: A method for classroom assessment. Journal of Marketing Education, 20(2), 85-93.

24. Ettington, D. R., \& Camp, R. R. (2002). Facilitating transfer of skills between group projects and work teams. Journal of Management Education, 26(4), 356-379.

25. Faria, A. J., \& Wellington, W. J. (1989). Strategic planning, group selection and time pressure as moderating variables on business game performance. Proceedings of the Southern Marketing Association, 201-205.

26. Feichtner, S. B., \& Davis, E. A. (1985). Why some groups fail: A survey of students' experiences with learning groups. Organizational Behavior Teaching Review, 9(4), 75-88.

27. Ford, M. \& Morice, J. (2003). How fair are group assignments? A survey of students and faculty and a modest proposal. Journal of Information Technology Education, 2, 367-378.

28. Gabbert B., Johnson, D. W., \& Johnson, R. (1986). Cooperative learning, group-to-individual transfer, process gain, and the acquisition of cognitive reasoning strategies. Journal of Psychology, 120(3), 265-278.

29. Hernandez, S. (2002). Team learning in a marketing principles course: Cooperative structures that facilitate active learning and higher level thinking. Journal of Marketing Education, 24(1), 73-85.

30. Hill, A. V., Naumann, D. J., \& Chervany, N. L. (1983). SCAT and SPAT: Large-scale computer-based optimization systems for the personnel assignment problem. Decision Sciences, 14(2), 207-220.

31. Holter, N. C. (1994). Team assignments can be effective cooperative learning techniques. Journal of Education for Business, 70(2), 73-76.

32. Jackson, S. E., Brett, J. F., Sessa, V. I., Cooper, D. M., Julin, J. A., \& Peyronnin, K. (1991). Some differences make a difference: Individual dissimilarity and group heterogeneity as correlates of recruitment, promotions, and turnover. Journal of Applied Psychology, 76(5), 675-690.

33. Jalajas, D. S., \& Sutton, R. I. (1984-85). Feuds in student groups, coping with whiners, martyrs, saboteurs, bullies, and deadbeats. Organizational Behavior Teaching Review, 9(4), 217-227.

34. Joyce, W. B. (1999). On the free-rider problem in cooperative learning. Journal of Education for Business, 74 (5), 271-274.

35. Kolb, D. A. (1984). Experimental learning: Experience as the source of learning and development, Englewood-Cliffs, NJ: Prentice Hall. 
36. Koppenhaver, G. D., \& Shrader, C. B. (2003). Structuring the classroom for performance: Cooperative learning with instructor-assigned teams. Decision Sciences Journal of Innovative Education, 1(1), 1-21.

37. Latting, J. K. \& Raffoul, P. R. (1991, Winter). Designing student work groups for increased learning: An empirical investigation. Journal of Social Work Education, 27(1), 48-59.

38. Levine, J. M., \& Moreland, R. L. (1990). Progress in small group research. Annual Review of Psychology, 41, 585-634.

39. McCain, B. (1996). Multicultural team learning: An approach towards communication competency. Management Decision, 34(6), 65+.

40. McClough, A. C. \& Rogelberg, S. G. (2003, March). Selection in teams: An exploration of the teamwork knowledge, skills, and ability test. International Journal of Selection and Assessment, 11(1), 56-66.

41. McCorkle, D. E., Reardon, J., Alexander, J. F., Kling, N. D., Harris, R. C., \& Iyer, R. V. (1999). Undergraduate marketing students, group projects, and teamwork: The good, the bad, and the ugly? Journal of Marketing Education, 21(2), 106-117.

42. McKendall, M. (2000). Teaching groups to become teams. Journal of Education for Business, 75(5), 277282.

43. McKinney, K. and M. Graham-Buxton (1993), The use of collaborative learning groups in the large class: Is it possible? Teaching Sociology, 21, 403-408.

44. McLagan, P. A. (1985). Helping others learn. Reading, PA: Addison.

45. Mello, J. A. (1993). Improving individual member accountability in small work group settings. Journal of Management Education, 17(2), 253-259.

46. Meyer, J. (1994). Teaching teams through teams in communication courses: Letting structuration happen. Paper presented at the annual meeting of the Speech Communication Association, New Orleans.

47. Michaelsen, L. K. (1994). Classroom organization and management: Making a case for the small-group option. In K.W. Prichard and R.M Sawyer's (Eds.) Handbook of College Teaching: Theory and Applications. Westport, CT: Greenwood.

48. Muller, T. E. (1989). Assigning students to groups for class projects: An exploratory test of two methods. Decision Sciences, 20, 623-634.

49. Norman, J. (2005). Speed-dating for the business world. Virginian-Pilot, March 20, K1.

50. Oliphant, G., \& Hansen, R. S. (1996). The job market approach to team formation. Marketing: Moving Toward the 21st Century (Southern Marketing Association Proceedings), 159-163.

51. Pfaff, E., \& Huddleston, P. (2003). Does it matter if I hate teamwork? What impacts attitudes toward teamwork. Journal of Marketing Education, 25(1), 37-45.

52. $\quad$ Pike, R. W. (1989). Creative training techniques handbook. Minneapolis: Lakewood.

53. Proll, L. G. (1972). A simple method of assigning projects to students. Operational Research Quarterly, 23, 195-201.

54. Rotfeld, H. (1998). Hello, bird, I’m learning ornithology. Marketing Educator, 17, 4-6.

55. Shea, J. H. (1995). Problems with collaborative learning. Journal of Geographic Education, 43(4), 306-308.

56. Siciliano, J. (1999). A template for managing teamwork in courses across the curriculum. Journal of Education for Business, 74(5), 261-264.

57. Simons, T. (1995). Interviewing job applicants - how to get beyond first impressions. Cornell Hotel and Restaurant Administration Quarterly, 36(6), 21-28.

58. Smith, K., Adams, S., Mendelson, S., \& Sibeck, G. (n.d.). Effective teams for the $21^{\text {st }}$ century. Retrieved Nov. 25, 2006, from http://www.nciia.net/proceed_01/Effective_Teams for the 21s.pdf

59. Spears, T. (2005). Speed-dating proves people follow their hearts, not heads. The Ottawa Citizen, Feb. 13, A4.

60. Strong, J. T., \& Anderson, R. E. (1990). Free-riding in group projects: Control mechanisms and preliminary data. Journal of Marketing Education, 12 (summer), 61-67.

61. Tarricone, P., \& Luca, J. (2002). Employees, teamwork and social interdependence - a formula for success in business? Team Performance Management, 8(3/4), 54-59.

62. Thacker, R. A., \& Yost, C. A. (2002). Training students to become effective workplace team leaders. Team Performance Management, 8 (3/4), 89-95.

63. Tonn, J. C., \& Milledge, V. (2002). Team building in an MBA 'gateway' course: Lessons learned. Journal of Management Education, 26(4), 415-428. 
64. van Vianen, C. K. W. \& De Dreu, A. E. M. (2001). Managing relationship conflict and the effectiveness of organizational teams. Journal of Organizational Behavior, 22, 309-328.

65. Verderber, K. S., \& Serey, T. T. (1996). Managing in-class projects: Setting them up to succeed. Journal of Management Education, 20(1), 23-38.

66. Williams, D. L., Beard, J. D., \& Rymer, J (1991). Team projects: Achieving their full potential. Journal of Marketing Education, 13 (Summer), 45-53.

67. Wulff, D. H., Nyquist, J. D., \& Abbott, R. D. (1987). Students' perceptions of large classes. In M. E. Weimer (Ed.), Teaching Large Classes Well. San Francisco: Jossey-Bass.

\section{NOTES}

